\title{
Review of Vincent Chiao, Criminal Law in the Age of the Administrative State
}

\section{Oxford University Press, Oxford, 2019, 270 pp}

\author{
Peter Ramsay ${ }^{1}$
}

Accepted: 16 July 2021 / Published online: 11 August 2021

(c) The Author(s) 2021

Vincent Chiao's Criminal Law in the Age of the Administrative State is an important contribution to the ongoing 'political turn' in criminal law theory. Chiao interweaves a relentless critique of the moral retributivism that has been the dominant form of criminal law theorising since the 1960s with his own alternative theory that he calls a 'fully political conception of criminal law'. Much of his critique of moral retributivism is compelling and it helps to force the pace of the political turn. Moreover, his own theory seeks to integrate the criminal law into an influential type of contemporary liberal political thinking. However, this theory is far from being 'fully political', as he claims, because it relies on too thin a view of the state. His critique overlooks the foundational problem of political authority. As a result, he offers a mirror image of the error of moral retributivism, an image that elides distinctive types of criminal law, and fails to pay sufficient attention to the political agency of citizens.

I will first set out the convincing elements of Chiao's critique of moral retributivism as a theory of the modern criminal law and then turn to his own 'political conception' of it.

In the book's first chapter Chiao argues that the moral retributivist account of state punishment coheres neither with the history of the criminal law nor the development of liberal political thought. The history indicates that from the early nineteenth century onwards the criminal law became increasingly state-centric and that it was deployed in pursuit of a fair distribution of the burden of risks of harm arising from lawful activities rather than to punish pre-political moral wrongs. He describes the claims of moral retributivists that the censure in criminal punishment involves everyday normative judgements or that criminal punishment requires no particular explication of the authority to punish beyond that provided by ordinary moral wrongdoing as nothing less than 'astonishing' (29) because they 'suggest a conception of coercive state power as simply [a] larger-scale manifestation of private moral

Peter Ramsay

p.ramsay@1se.ac.uk

1 Department of Law, London School of Economics, London, UK 
relationships', a conception that is 'dramatically at odds with most forms of political liberalism' (29). The latter have long been centrally concerned with securing the conditions of civic equality and flourishing (30), with what could broadly be called welfare states. For Chiao this doesn't necessarily mean that no case can be made for retributive justice but rather that 'the argument that securing retributive justice could be a legitimate function of the welfare state should be defended on the field of substantive political morality'. The question that moral retributivism evades is 'Why, when the pursuit of retribution conflicts with other political values that we have reason to care about, should preference be given to retribution?' And this question, Chiao points out, cannot be answered by 'reflection on interpersonal morality' (31).

In Chapter 4, Chiao turns to a question in which the pursuit of retribution does seem to conflict markedly with other political values, the experience of mass incarceration. He observes the palpable irony that, although modern retributivism developed to overcome the excesses of state power supposedly licensed by a once-dominant utilitarianism, it turns out that 'strictly deontological theories lack the resources to constrain the growth of the carceral state' because they are uninterested in the wider costs or benefits of state punishment. The fact that the harms of crime might be managed both more economically and with much greater respect for the equality of citizens by investing in schools rather than prisons is of no concern to moral retributivism as such. If individuals have committed offences that deserve severe treatment such as incarceration, then moral retributivism licenses or even requires that the individuals are incarcerated.

In Chapter 5, Chiao develops an account of the reasons the state has to criminalise conduct and demonstrates that pre-political moral wrongdoing can provide neither a sufficient reason nor a necessary constraint on criminalisation. It cannot be a sufficient condition because there is simply too much sincere disagreement about pre-moral wrongdoing for a society that is in any way committed to the freedom and equality of its citizens to tolerate criminalisation on that basis alone (169). Moral wrongfulness cannot serve as a constraint on criminalisation unless we are willing to abandon the use of the criminal law to back up regulatory regimes, including such basic offences as tax evasion (173). The question of what we criminalise and what we don't therefore requires us 'to look at criminal law from a public law point of view' as a matter of what the state ought to do (181).

In the book's last chapter, Chiao takes on perhaps the most powerful claim of retributivism: that without a system of retributive punishment, the state fails to treat its citizens as responsible agents through holding them to account for their wrongdoing. In an incisive argument, he points out that in fact the state only holds to account those it successfully identifies as offenders and that many offenders get away with it. The consequence is that, even if vindicating the idea of individual responsibility still gives the state reason to hold the offenders it knows about to account, which offenders, and how many, will in fact be held to account nevertheless depends on the resources that the state devotes to detection and prosecution, as opposed to other services, including many other ways in which the state might promote individual responsibility. In other words, even the vindication of responsibility by retributive punishment cannot be independent of the political consideration as to where the state should put its resources, what it should prioritise. 
Each of these arguments gives us strong reasons to reject moral retributivism and this is true even for those of us who are not liberals. As Chiao demonstrates, the moral retributivist account cannot explain the law that we have; has little to offer in respect of the primary problems of criminal justice today; and cannot even give an explanation of the practical significance of what it claims to be retributivism's key contribution, vindicating the status of the law's subjects as responsible agents.

Chiao interweaves this critique of moral retributivism with the development of his own public law conception of the criminal law. This is based on the political ideal of status equality that, following Philip Pettit, Chiao calls 'anti-deference'. The ideal is that 'people should be able to live on terms that do not require them to show deference before others' (73). Chiao emphasises the democratic aspect of this equality in which people subject to the law have 'an equal say in determining its content' (74). This in turn requires equal access to 'central capabilities' on terms 'befitting an equal' (75), where a central capability is 'a state or activity that contributes to a person's well-being' that is 'required...to secure a life without shame' (194-95). The key point that arises from the anti-deference idea is that justice in such a state will seek to prevent crime and to respect individual responsibility by spending its resources on 'schools now' rather than 'prisons later' (101).

Liberals might want to argue with Chiao's particular theory, but I will assume that it is a reasonable account of what a contemporary welfarist liberal might support. My problem with Chiao's account is that it is not the 'fully political conception' that he claims it to be. At best it is only a partially political conception. His theory is completely focused on the distribution of social advantage by the state. But at no point does Chiao ask what the state is. Seeing only its function in a normative theory of justice and overlooking the nature of the state that will do the justice, he also overlooks the foundational position of the criminal law in the constitution of the modern state.

In his brief history of the emergence of modern criminal law in the first chapter, Chiao implicitly dismisses the political theory tradition of Hobbes, Locke, Rousseau and Hegel with a quick Foucauldian gesture borrowed from David Garland in which the figure of the sovereign belongs to the premodern era that was abandoned as the modern state adopted its administrative functions (12-13). At a stroke, the entire problem of political authority is avoided, and the concept makes no appearance.

In the second chapter, the criminal law is presented as a 'generically rule-enforcing institution' (36) that 'stabilises a public sense of justice by providing assurance that cooperation with legal rules will not leave one open to victimization or exploitation' (37). In this account the state with its public law provides a technical solution to the game-theory problem of the prisoner's dilemma and a mechanism for achieving a normatively ideal state that guarantees social cooperation. Like public law generally the criminal law is just 'a means of allocating social advantage' (67), so that for Chiao the place to start is 'with a conception of justice in public institutions' (159). But starting with 'a conception of justice in public institutions' assumes that we already know what public institutions are. Chiao claims to provide a 'fully political standard' for assessing the justice of the criminal law but skips over what sort of entity is able to make or enforce these rules for the distribution of social advantage in the first place. 
The state is an association of its subjects in which they consent to be ruled by some institutions that have law-making competence. This political association of the subjects is formed by being represented by the public office of the sovereign. The political character of the state lies precisely in this relationship of representation through which the sovereign institutions, as the representative of the subjects' association, acquire political authority or sovereignty - the autonomous right to make rules and to enforce them. ${ }^{1}$ Moreover, the liberal or democratic state is an association of persons, of moral agents who have the capacity to determine their own ends in life, to decide how to achieve those ends and to consent to being ruled by a body with ultimate law-making power in order to do so. And if the sovereign's political authority to make coercive rules is to be maintained then its public law will need to realise these rights of agency that belong to the persons the sovereign represents. The protection of these rights of agency is not merely another 'social advantage' or 'central capability': it is at the foundation of the state's authority. But 'rights' is a word that makes barely any appearance in Chiao's book.

As a result of an only partially political theory that overlooks the question of political authority, Chiao gives an account of the criminal law that is as one-sided as the retributivist account he rightly criticises. Where moral retributivists struggle to give an account of regulatory strict liability as anything other than anomalous, Chiao collapses the legal distinctions between different types of coercive public law in order to obscure the distinctive aspect of the criminal law that moralists misread.

His history of the criminal law notes the emergence of a state-centric prosecution system along with the rise of the regulative aspect of the state but then makes nothing of the striking fact that offences of violence and interpersonal trespass retain the distinctive feature of subjective mens rea, which is both unique to the criminal law and yet not required by most of the offences that enforce regulatory schemes. Moreover, as he notes, these are the offences that make the most significant contribution to the inflated prison population (153). In his discussion of criminalisation, Chiao allows that these 'mala in se offenses are often plausibly construed as attacks on free and equal citizenship' (159), but he does not explore the possibility that this might make them in some sense different to other criminal offences from the point of view of a political conception. Instead, he argues that their structure and enforcement should simply be subjected to a singular conception of justice as anti-deference.

He pays no attention to the distinctive political role of subjective mens rea requirements in the offences of interpersonal trespass because this role arises from the need to realise the rights of personhood that are foundational to the state's authority, a question he has overlooked. As Alan Brudner argues, ${ }^{2}$ proof of mens rea is proof that the offender deliberately violated another subject's rights so that the crime amounted to a practical denial of the existence of those rights. This establishes a distinctive political rationale for punishing the offender: it is necessary in order to realise the authority of rights and the nullity of their denial by acting out the

\footnotetext{
1 This account is drawn from Martin Loughlin, The Idea of Public Law (Oxford University Press, 2003) 81-86.

2 Alan Brudner, Punishment and Freedom (Oxford University Press, 2009) Chp 1.
} 
denial on the denier. In the same moment, it provides the state with the authority to deny to the offender the very rights that are the state's raison d'etre. The authority comes from the offender herself, who has in practice denied the existence of individual rights through her own deliberate criminal conduct.

There are plenty of reasons to doubt the justice of this legal retributivism from an ideal standpoint. I agree with Chiao that the resources the state spends on its penal institutions would be better spent avoiding crime in the first place by creating conditions in which more people are able to live more constructive lives, and that doing this can also be respectful of them as responsible agents. Both liberal and democratic states have good reason to minimise their reliance on criminal justice. But the sovereign's right to punish in this way cannot be given up without giving up the state's foundational claim to political authority. This symbolic, ideological dimension to criminal law is a closed book to any theory that assumes away the foundational problem of political authority.

Chiao rejects Brudner's legal retributivism as just one more 'variant of strict deontological theory', which denies that justifiable punishment needs to 'achieve socially desirable ends' (116). He accepts that impunity might be harmful for the social cooperation that he thinks the law must achieve, so that there may be some residual role for an expressive function of punishment, but this is just another way of achieving the socially desirable end of cooperation (240-43). He does not consider the specific connection between the vindication of rights of agency and the political authority of the liberal or democratic state, because he does not consider the nature of the state.

Of course, a fully political public law conception of criminal law must combine this understanding of the politically foundational role of the 'true crimes' with an explanation of the regulatory offences. That can be done as soon as we take into account that the rights to control one's person and property-rights of agency-are not sufficient for the freedom or for political equality that a liberal or democratic state must guarantee; that all sorts of other capabilities or agency goods are also required, and that the criminal law plays a part in distributing them. ${ }^{3}$ But Chiao's account omits the prior political question of the personhood of the law's subjects as agents who are constituted into a state by a sovereign that realises their rights of personhood. Instead, he merges that criminal law indifferently with administrative law.

Chiao is rightly appalled by the growth of the carceral state, and he hopes that his welfarist theory of justice can reorient the state's priorities by abandoning retributivism. But overlooking the character of the state's authority means that the personhood and agency of citizens - upon which liberalism was founded and which will be essential to any rollback of the carceral state-are theoretically marginalised. Chiao might well object that an equal status entails being able to move about, express opinions, choose associates, organise politically and so on, and these are all 'central capabilities'; but so are bodily integrity, or access to adequate healthcare, or sufficient self-esteem and so on. All are capabilities to be traded off against each other by a 'democratic' state in pursuit of equality and anti-deference. The rights of persons as agents are not distinct from other goods, and this not only mystifies the

\footnotetext{
3 See Brudner, Punishment and Freedom, Chp 5.
} 
structure of criminal law as public law but has potentially subversive consequences for democracy.

For all Chiao's concern to give democracy a central place in his political theory, the anti-deference version of political equality seems slippery and not to take citizens' agency and independence all that seriously. Chiao endorses the contemporary liberal shibboleth of voting rights for prisoners on the grounds that 'those subject to the law should have an equal voice in shaping it' (82). But prisoners by definition lack the freedom of association, of assembly, of movement and of private life that other citizens enjoy. The effect of accepting Chiao's liberal argument is to eliminate these civil liberties as necessary conditions of equal political citizenship.

A still more dystopian potential of penal welfarism is implicit in Chiao's rejection of the US Supreme Court's decision, in DeShaney $v$ Winnebago, that a child's constitutional right to liberty was not violated by a local social services department's failure to protect him from his abusive father when social workers were aware of the risk that the child faced. Putting state agencies under a constitutional duty to protect citizens' bodily integrity in the face of a known risk from another person opens the door to the most risk-averse invasions of individual liberty. Chiao thinks that 'the law should ensure that no party to a private relationship is under the thumb of any other party' and that the criminal law has a legitimate role to play in this (5). Once that principle is established then the state will surely come under a duty not to fail to know when a person may be being put under another's thumb. We should consider carefully the possibility that nobody will have to defer to any other private party for as long as we are all under the liberal gaze of the penal panopticon.

Open Access This article is licensed under a Creative Commons Attribution 4.0 International License, which permits use, sharing, adaptation, distribution and reproduction in any medium or format, as long as you give appropriate credit to the original author(s) and the source, provide a link to the Creative Commons licence, and indicate if changes were made. The images or other third party material in this article are included in the article's Creative Commons licence, unless indicated otherwise in a credit line to the material. If material is not included in the article's Creative Commons licence and your intended use is not permitted by statutory regulation or exceeds the permitted use, you will need to obtain permission directly from the copyright holder. To view a copy of this licence, visit http://creativecommons.org/licen ses/by/4.0/.

Publisher's Note Springer Nature remains neutral with regard to jurisdictional claims in published maps and institutional affiliations. 